\title{
The Gowe Irrigation co-operative society and its role in Sanyati (Zimbabwe), 1967-1969
}

\author{
M NYANDORO
}

\begin{abstract}
The paper focuses on the origins and development of agricultural co-operative societies in Zimbabwe since 1954 with particular reference to Gowe-Sanyati and evaluates their role in facilitating the channelling of production inputs to farmers and the marketing of their produce. It examines the criteria for eligibility to membership of such associations, namely who could belong and who could not, as well as their administrative structures and practices. In addition, the paper evaluates the societies' impact on their members, on African development and on the national economy.

In 1954 the Government of Rhodesia (now Zimbabwe) began investigations on the need for co-operative societies (co-ops) in order to promote African development through facilitating the acquisition of production inputs and the marketing of agricultural products. In 1956, the first co-operative society was established, while the main focus of this paper's interest, the Gowe Irrigation Co-operative Society of Sanyati in the northwestern part of the country, was established in 1967. Established by a government agency known as the Tribal Trust Land Development Corporation (TILCOR), now the Agricultural and Rural Development Authority (ARDA), the co-operative society flourished and became a model for the distribution of agricultural inputs and credit to African farmers. It collapsed in 1969 due to a number of factors, among them poor management and corruption.
\end{abstract}

\section{Keywords}

agricultural so-operative societies in Zimbabwe, Rhodesia, Sanyati, irrigation, Zimbabwe (Rhodesia), African farmers, trust lands.

\section{Disciplines}

History, economic history, agricultural history.

* $\quad \operatorname{Dr}$ M (Mark) Nyandoro is an economic and socio-economic historian attached to the project South African history online.

TD: The Journal for Transdisciplinary Research in Southern Africa, Vol. 3 no. 2, December 2007, pp. 319-350 


\section{Introduction}

The co-operative system is the offshoot of British utopian socialism. Its ideology was provided by Robert Owen. "Out of Owenism came the ideas, doctrines, myths and much of the inspiration which is associated with the co-operative movement." 1 The essential characteristic of this ideology was the reaction to the excesses of competitive capitalism in the wake of industrial revolution. It was the revolt against the exploitation of workers by the early industrialists, the associated impoverishment of rural areas, the dire living conditions of the urban masses, unrestricted competition and greed. 2 Specifically, competition was opposed by the ideal of co-operation; individualism by collectivism; private property by social ownership; profit by sharing of surplus; inequality by equality; and materialism by the development of moral character through co-operative education. ${ }^{3}$ Underlying these ideals were a distinct philosophy and ethics. Against the philosophy of natural economic laws, the cooperative philosophy stressed group action and social reforms. ${ }^{4}$

This paper is an examination of the operations of the co-operative system in an agricultural context. However, the co-operative movement needs to be put in its internationalist perspective since the origins of the movement are not typically Zimbabwean. It is important to note that although the concept of co-operation is older than mankind, the idea of a co-operative system is the product of the nineteenth century. A co-operative is not merely an economic or social institution such as a corporation, family or partnership. It is part of a distinct socio-economic system. ${ }^{5}$

1 Gregory Grossman, "The Second Economy of the USSR," Problems of Communism, 26(5), (September-October 1977), 25-40. See also Arnold Bonner, British Co-operation, (Manchester: Cooperative Union, 1961).

2 Leonard Pluta, "The Cooperative System and Central and Eastern Europe in the Nineteenth Century," in Aloysius Balawyder (ed.), Cooperative Movements in Eastern Europe, (London: MacMillan Press Ltd., 1980), 1.

3 Ibid. , 3-4.

4 Ibid. , 4.

$5 \quad$ Ibid. , 3. 
Apart from Britain numerous formal co-operatives with varying degrees of success emerged in nineteenth-century Germany, France, Denmark, Holland, Luxembourg, Ireland, Belgium and Italy to name a few. ${ }^{6}$ In Asia the Indian Societies Act under which a number of groups were registered was passed in 1860, and the first Indian Cooperative Act was passed in 1904. ${ }^{7}$ Co-operatives in India were formally recognised and promoted as it was increasingly felt that cooperation could benefit people in the colonies. Co-operation and cooperative marketing in agriculture is, thus, not a novel phenomenon. The history of the co-operative movement goes back almost a hundred years.

The following definitions of co-operative activity are very useful to an understanding of how the system operated. The International Labour Organisation (ILO) defines co-operative enterprise as

\begin{abstract}
... an association of persons, usually of limited means, who have voluntarily joined together to achieve a common economic end through the formation of a democratically controlled business organisation, making equitable contributions to the capital required and accepting a fair share of the risks and benefits of the undertaking. ${ }^{8}$
\end{abstract}

The International Co-operative Alliance (ICA), at its Manchester Congress in September 1995, adopted a statement on co-operative identity. This statement similarly defines a co-operative as: "an autonomous association of persons united voluntarily to meet their common economic, social and cultural needs and aspirations through a jointly-owned and democratically controlled enterprise." 9

6 For a comparative analysis of performance, the role played by agricultural cooperative organisations in the determination of marketing arrangements and the effects of organisation on the marketing strategies of selected European countries' co-operative sectors see Gordon R. Foxall, Co-operative Marketing in European Agriculture, (Aldershot, Hampshire, England: Gower Publishing Company Limited, 1982), 1-101. An examination of the co-operative system or movement in Central and Eastern European countries can be gleaned from Balawyder (ed.), Cooperative Movements in Eastern Europe, 1-211.

7 Malcolm Harper and A. K. Roy, Co-operative Success: What Makes Group Enterprise Succeed, (London: Intermediate Technology Development Group/ ITDG Publishing, 2000), 140.

8 ILO, Co-operative Management and Administration, (Geneva: International Labour Office, 1971).

9 ICA, "Agenda and Reports," Review of International Co-operatives, 8(3), Manchester: ICA Congress, (1995). 
On the whole, though, the concept of co-operative organisation is far from homogeneous. There are many forms of co-operative organisation, and there are decisive differences in how they are organised and how they work. Co-operative organisation ranges from traditional co-operative models to socially involved and governmentsupported co-operation. The primary focus of this paper, the Gowe ${ }^{10}$ Irrigation Co-operative Society in Northwestern Zimbabwe, was akin to the latter model.

Thus, agricultural co-operative enterprise in Zimbabwe will be discussed in the context of these definitions, which bear close resemblance to the meaning of the same concept as it applied to the Gowe-Sanyati situation. Just like other similar organisations elsewhere, the Gowe Co-op, as it became affectionately known, was informed by the need to maximise agricultural production on the basis of collectively harnessing resources for the benefit of all the irrigation plotholders ${ }^{11}$ in the Sanyati region.

The paper primarily focuses on the origins and development of agricultural co-operative societies in Zimbabwe with particular reference to the Gowe-Sanyati Irrigation Co-operative Society, which emerged in 1967 (See map of location of Co-op Societies in Zimbabwe).

In the process, it evaluates these institutions' role in facilitating the channelling of production inputs to farmers and the marketing of their produce. Established by a government agency known as the Tribal Trust Land Development Corporation (TILCOR), now the Agricultural and Rural Development Authority (ARDA), the cooperative society at Gowe flourished and became a model for the distribution of agricultural inputs and credit to African farmers.

The study examines the criteria for eligibility to membership of such associations, namely who could belong and who could not, as well as their administrative structures and practices. In addition, the paper

10 Gowe is a smallholder irrigation scheme administered by the Agricultural and Rural Development Authority (ARDA). It is situated in the Sanyati Communal Lands in Mashonaland West Province. The scheme should not be confused with Gokwe which is a vast district in the Midlands Province of Zimbabwe.

11 In this paper the term plotholder is used to mean tenant, outgrower, settler or smallholder irrigation farmer. 
evaluates the societies' impact on their members, on African development and on the national economy. It ends by analysing the factors, among them poor management and corruption, that led to the collapse of this society in 1969. It can be pointed out that in this paper, a number of non-African examples have been selected in order to indirectly provide some guidelines as to what can be done locally.

\section{The co-operative movement and rural development}

Historically, the Co-op movement in Rhodesia (now Zimbabwe) emerged in the 1950s. In 1954, the colonial government began investigations on the need for co-operative societies in order to promote African development through facilitating the acquisition of production inputs and the marketing of agricultural products. It was found that while urban societies would have little value, agricultural societies would provide a needed service in the channelling of both input items to African farmers and the produce of these farmers to marketing bodies. Thus, co-operative societies would provide a mechanism by which credit for the purchase of input items could be made available to African farmers. It should be noted that early efforts to establish co-operatives were concentrated on the African Purchase Lands, formerly African Purchase Areas (APAs) and now small-scale commercial farms, because of their more advanced farmers and greater output.

Following the formation of the first society in the APA (i.e. in Chitomborwizi in 1956), the first in a Tribal Trust Land (communal area) was set up in Madziwa in 1960. In the 1963/64 season there was only one co-operative in the main cotton growing area of Munyati. This was the Umniati/ Munyati Co-operative (in Gokwe district), which was formed in 1961. By 1966, there were six such co-operatives in the cotton growing areas, and cotton accounted for $80 \%$ of their business. ${ }^{12}$ Co-operative societies have been the main vehicles of

12 Murimi, December 1966, Press Statement, "Gokwe farmers have record cotton crop," Ministry of Information, 7 December 1966. See also P. S. Nyambara, "A History of Land Acquisition in Gokwe, North Western Zimbabwe, 1945-1997," PhD Dissertation, North Western University, Evanston, Illinois, June 1999, 245-246.

TD, 3(2), December 2007, pp. 319-350. 
rural development in Zimbabwe and nearly everywhere. They were established and managed by individuals or groups of individuals mainly for their own benefit or profit. Hence, there were too many examples of exploitation, where co-operative enterprises actively damaged the interests of others as will be demonstrated in this study.

Since the end of the colonial era, co-operation has been seen as a way of enabling indigenous people to take over the control of their own lives from alien business. It seemed to have the potential to release the poor from the domination of capitalism and of foreigners. As a consequence, co-operative enterprises were eagerly promoted by the governments of newly independent countries in many parts of the world. ${ }^{13}$ Foreign donors, both government and non-government, assisted enthusiastically. Nonetheless, not all of them could point to a universally successful co-operative movement in their own countries, and none could claim that co-operation had been their major source of economic growth, but this did not necessarily mean that they had nothing to offer.

There have been some successes and many failures. The recent history of the former Soviet Union and Eastern Europe, where government-sponsored co-operatives have been discredited along with state enterprises, has not only been replicated as far as the Gowe Irrigation Co-operative Society in Sanyati was concerned but also contributed to a general climate of scepticism about any form of group enterprise. Although this study recognises the successes, it also makes a veritable and modest attempt to identify the major factors, which were associated with failed group enterprise in Gowe agriculture in the late 1960s.

It is a fact that co-operatives have been widely discredited, in as much as it is true that their many failures have frequently been the result not of intrinsic faults with the concept of group ownership, nor of members' own mistakes, but of overzealous and misdirected efforts

13 ICA, "Agenda and Reports," Review of International Co-operatives. 
by governments or other agencies which have tried to promote them. 14 As governments, at every level, were withdrawing from many fields, co-operatives and those who wished to promote them were faced with new freedom and challenges. They were vested with more power to make their own decisions, but they needed to learn as much as possible from the experience of the past. For instance, there is a great need for effective new co-operative enterprises, and a perhaps even greater need to rehabilitate or restore older ones to profitable operation. ${ }^{15}$ The Gowe one, for instance, was immediately subordinated to the main Co-operative Union based in Que Que (now Kwekwe), which was known as Sebungwe and ultimately to the state. Because of this, its decisions were often externally influenced. Such a situation, therefore, inevitably limited its autonomy and indeed reduced its chances of success. This is contrary to Shah's view that co-operatives can only be successful when they are evolved totally "naturally," without any external assistance or inspiration. ${ }^{16}$ The Gowe Co-op prioritised input distribution without changing the criteria for choosing members and without placing much emphasis on the tenets of equity. It was also hardly totally free of government interference.

In Zimbabwe, it was very difficult for any co-operative society to avoid state interference or even virtual state control. The state had penetrated the co-operative movement so thoroughly that many cooperatives were effectively little different from state-owned enterprises. ${ }^{17}$ However, it was possible for co-operatives in Sanyati where the hand of the state was as pervasive, and sometimes

14 Harper and Roy, Co-operative Success, 4.

15 Ibid.

16 Tushaar Shah, Catalysing Co-operation, (New Delhi: Sage, 1996), 20-21. See also T. Shah and D. Mishra, "Analysing Under-Performance in Indian Cooperatives," Small Enterprise Development, 3(1), (1993); H.O. Srivastava and M. K. Chaturvedi, Rural Middlemen, (New Delhi: Ashish, 1986); ILO, Co-operative Management and Administration, (Geneva: International Labour Office, 1971); G. Hunter, Modernising Peasant Societies, (Oxford: Oxford University Press, 1969) and A. Hanel, State-Sponsored Co-operatives and Self-Reliance, (Marburg: Institute for Co-operation in Developing Countries, 1989.

17 NAZ (RC), ARDA, Box 272099, Location R19.3.12.1F, File: ADA/MAR/2 Marketing - General, "Confidential Correspondence: Agricultural Development Authority - Co-operative Societies in African Areas," 26th January 1973. See also Harper and Roy, Co-operative Success, 131. 
destructive, as almost anywhere in the country, to succeed in spite of this. For some time after 1967, it appeared the co-operative movement would succeed at Gowe. Subsequent events especially those linked to the collapse of this Co-op in 1969, and indeed many others in the rural areas, seem to confirm the point observed in many circles that state control is damaging, in that most societies that failed in this period were among those which were effectively under the control of the state. ${ }^{18}$

The National Dairy Development Board (NDDB), for example, represents perhaps the most enlightened and certainly the most successful group of co-operatives in India, and it is worth quoting their view of the roots of failure, and thus, by inference, of the nature of success, in full:

\footnotetext{
Without the critical links of responsibility and accountability between member and board as well as between board and professional management, a co-operative system functions more as a bureaucratic department and less as a member-owned enterprise. Decisions are taken in the interests of others than the members and the co-operative structure, rather than serving its owners, tends to become a vehicle for government programmes and political agendas. This, in turn, erodes the quality of management and, ultimately, threatens the long-term viability of the co-operative system. ${ }^{19}$
}

These reasons for failure were not very different from the factors that led to the collapse of the Gowe Co-op in Zimbabwe. State involvement could hardly be dispensed with, as members never expressed their willingness to sacrifice the political connections, subsidies and other assistance that accompanied official co-operative status. Any attempt to avoid association with government officials was seen as detrimental to their continued quest to get constant supplies of farm inputs.

Ibid. , 132 .

19 NDDB, A Note on Co-operative Development, (Anand, India: National Dairy Development Board, 1991). 
An apolitical stance would have helped enhance their autonomy and ultimately their performance. In fact, when the Co-op was established some tenants were not against initial assistance coming from it, but with the passage of time, a rather larger rural constituency believed that continuing subsidy was not consistent with success. However, this view is somewhat paradoxical since it was virtually impossible for any officially recognised group enterprise in Zimbabwe to escape subsidy, and groups often registered themselves solely in order to be eligible for assistance. In spite of this argument, however, there seemed to be unanimity among the smallholder irrigation farmers in Sanyati that co-operative societies should not have had close political links. ${ }^{20}$

The co-operative movement in the world in general and in Zimbabwe in particular has suffered greatly because the concept has so often been "hijacked" by governments, and by foreign donors, as an instrument of political patronage, and of "top-down" development, with little reference to the traditions or the wishes of the membership. ${ }^{21}$

Whenever this happens inclinations towards exclusion become more entrenched as long as co-operative members are not given much say in the running of the institution that disburses vital inputs to them. They often find themselves at the mercy of inept and corrupt officials. It can further be pointed out that a successful co-operative is one that adheres to the standards of profitability and growth enunciated at inception, which was not the case at the Gowe Small-Scale Irrigation Scheme. Given the fact that the scheme was only 120 hectares in size, ${ }^{22}$ membership tended to be very stagnant, and static membership can be one of the flagships of failure. Membership should be dynamic as well as goal and profit-oriented. Best practice in performance can be represented by an evaluation of profitability. In the Indian cooperative sector, "sound performance" is said to be:

20 T. Nyamutova, Vice Chairman, Gowe Irrigation Committee, Personal Interview, Gowe, 14th May 2005.

21 NAZ (RC), ARDA, Box 272099, Location R19.3.12.1F, File: ADA/MAR/2 Marketing - General, "Confidential Correspondence: Agricultural Development Authority - Co-operative Societies in African Areas," 26th January 1973 and Harper and Roy, Co-operative Success, 139-140.

22 J. Gwerengwe, "Sanyati Estate Corporate Plan," ADA, (1995), 1. 
characterised by financial viability, adherence to basic principles of co-operation, satisfaction of member objectives, centrality to members' economies, growth in membership and business, and member involvement in the co-operative's affairs. ${ }^{23}$

This suggests that the country pursued a sustainable co-operative policy. ${ }^{24}$ Whilst the Indian Co-ops strove to achieve this, nonetheless, these very necessary conditions were hardly satisfied at Gowe where farming on a co-operative basis was gradually subordinated to officials' interests. ${ }^{25}$ The local Co-op, thus, became an instrument for the exclusion of members' interests and not one that sought to promote the original principles governing co-operation. A detailed examination of farmers' access to co-operative credit at Gowe-Sanyati demonstrates the extent to which the Co-op advanced the interests of its members.

\section{Co-operation in Practice}

\section{Access to credit and the co-operative movement in Sanyati}

In Sanyati, with the introduction of both dryland and irrigated cotton, the local farmers had become almost totally involved in the cash crop economy, ${ }^{26}$ with some individual households emerging as cash rich or cash poor. These differences, among other things, emerged against

23 T. Shah and D. Mishra, "Analysing Under-Performance in Indian Cooperatives," Small Enterprise Development, 3(1), (1993).

24 For comparative Tropical African examples of co-operative agricultural policies, see Robert H. Bates, Markets and States in Tropical Africa: The Political Basis of Agricultural Policies, (Berkeley: University of California Press, 1981).

25 NAZ (RC), DC Gatooma, Ministry of Internal Affairs, Box 158098, Location C19.10.7R, DC's File: Gowe Irrigation Scheme: Financial Plans, Water Reports etc, 1967-1971, "Sanyati Irrigation Plots," 1-2.

26 Mark Nyandoro, "The Gowe Plotholders Scheme: Growth and Development of an African Irrigation Enterprise in the Sanyati Communal Lands (1960s1990s), MA thesis, Harare: Department of Economic History, University of Zimbabwe, June 1997. See also E. N. S. Chicheko, "A History of Cotton Growing in Sanyati (1968-1990)," BA Honours dissertation, Harare: Economic History Department, University of Zimbabwe, 1992. 
the backdrop of peasant households' differential access to some of the most critical productive resources for successful cotton production. ${ }^{27}$ It is important to observe that growing a cash crop such as cotton not only generates cash, but it requires inputs such as capital, market access, labour and good quality land. ${ }^{28}$ However, at the Gowe Smallholder Pilot Irrigation Scheme ${ }^{29}$ access to capital was a major constraint for most plotholder households.

The prime source of finance to the peasant farmer in colonial Zimbabwe was the Agricultural Loan Fund (ALF), established in 1958 and administered by the African Development Fund (ADF). ${ }^{30}$ It was through the promulgation of the Co-operative Societies Act of 1956 that the supply and marketing co-operatives became the principal means for peasant farmers' access to inputs and markets. In other words, co-operatives were the main channel through which members could sell their crops (cotton, wheat and maize), ${ }^{31}$ and also obtain commoditised inputs (i.e. seed, fertilisers, insecticides and pesticides) on credit. This contributed to rapid growth in cotton production, which to some extent was associated with the Gowe Co-op and the major finance institutions of the time. ${ }^{32}$

27 Pius S. Nyambara, "A History of Land Acquisition in Gokwe, North Western Zimbabwe, 1945 - 1997," Ph. D Dissertation, North Western University, Evanston, Illinois, June 1999, 244-245.

28 Ibid. , 245.

29 The scheme which was established in 1967 was administered jointly by the District Commissioner (DC) for Gatooma and TILCOR.

30 Nyambara, "A History of Land Acquisition in Gokwe," 245.

31 The Regional Co-operative Officer, K. Hahn, insisted that ideally, members were supposed to sell their maize through the Co-op. See NAZ (RC), DC Gatooma - Ministry of Internal Affairs, Box 158098, Location C19.10.7R, File: "Gowe Irrigation Scheme: Sanyati TTL (EX CONEX)," Minutes of a meeting held at Gowe Irrigation Scheme on 5th May, 1969, 1.

32 N.B. The phenomenal expansion of cotton during the late 1960s and early 1970 s was largely associated with the activities of the co-operative societies. By 1969, there were 267 registered co-operative societies in the country, 190 of them operating in African areas and relying heavily on government support. See A. K. H. Weinrich, African Farmers in Rhodesia, (London: Oxford University Press, 1975), 28-33. 


\section{Gowe: The role of the ADF, ALF and the co-operative society}

With the inception of the Gowe Irrigation Scheme in 1967, the ADF provided tractors for ploughing and recovered its costs from the plotholders as ox-drawn ploughs were not allowed. ${ }^{33}$ Norman Savata Gwacha, who cultivated a 1,4 hectare ( 4 acre) plot remembers that in that year the ADF tractor service for ploughing was provided at the rate of $£ 10(\$ 20)$ per plotholder. ${ }^{34}$ Primarily, the ADF was involved in the financing of the smallholder scheme, the provision of farm equipment and the financing of the cropping activities. The prime source of credit to the Gowe irrigators was the ALF, and by the simple expedient of paying a nominal membership fee, these farmers had access to full seasonal credit through their co-operative society, the Gowe Co-operative Society - a subsidiary of the Sebungwe Cooperative Union.

Since 1967, the growth of the co-operative movement was steady. ${ }^{35}$ From the 1960s, the societies were controlled by the Co-operatives Branch of the Ministry of Internal Affairs, which administered both

33 Livestock rearing was not permitted within the confines of the irrigation scheme because tractors and other agricultural equipment were provided by the ADF. There was also no provision for grazing land within the scheme, but a livestock-fattening programme had been introduced by the livestock demonstrator for farmers to sell beasts and make a handsome profit. See A. Masenga, Gowe Pump Attendant, Personal Interview, Gowe, 8th January 1997 and R. L. Westcott, Former DC Gatooma, Personal Interview, Ramsgate, South Africa, 12 July 2005.

34 Norman Savata Gwacha, Communal farmer and former Secretary of the Gowe Irrigation Co-operative Society, Personal Interview, Kusi Village, Sanyati, 9th January 1997 and 15th May 2005.

35 At the end of 1972, three years after the collapse of the Gowe Co-op, there were 291 primary societies - marketing and agricultural supply societies with 33000 members. These primary societies were later amalgamated into 11 marketing unions (secondary societies) in order to consolidate the negotiating power of the primary societies. See NAZ (RC), ARDA, Box 272099, Location R19.3.12.1F, File: ADA/MAR/2 Marketing - General, "Confidential Correspondence: Agricultural Development Authority - Co-operative Societies in African Areas," 26th January 1973, 1. 
the Co-operative Companies Act and the Co-operative Societies Act. The Co-operative Societies Act was an enabling Act only, which provided the apparatus for the formation and registration of cooperatives. Strong controlling and inspection powers were provided to the Registrar by the Act. By the end of 1967 the Sebungwe Cooperative Union Limited incorporated 27 co-operatives in the Gokwe, Gatooma and Que Que areas. ${ }^{36}$ The Union provided several functions. For instance, (a) it amalgamated member co-operatives into a single purchasing body; (b) acted as banker for the co-operatives; channelled all payments for crops through itself and made it feasible for primary co-operatives to operate retail stores. ${ }^{37}$

The Union, which was staffed and managed solely by Africans, operated a central warehouse in Que Que, a pesticide packaging plant, three heavy trucks with trailers and a sizeable number of tractors for the provision of tillage services. ${ }^{38}$ It was this warehouse that supplied the needs of smaller co-operatives such as Gowe. The basic reason for the existence of the co-operatives was to meet the individual member's problems in the financing of his crop (credit), the supply and transport of input items into the farming area, and the transport of produce out of it to the market. To obtain credit well in advance of the growing season, a member submitted to his local committee his list of requirements for seed, fertiliser and pesticides. ${ }^{39}$

The committee, on advice from co-operative staff, ensured that the amounts requested were in balance with the intended acreage. A member was required to sign a stop order in favour of the co-operative for the cost of these items, plus handling and transport charges. The individual member's loans were consolidated into a single cooperative loan and application made to the District Commissioner

36 NAZ (RC), ARDA, Box 272099, Location R19.3.12.1F, File: ADA/MAR/2 Marketing - General, "Confidential Correspondence: Agricultural Development Authority - Co-operative Societies in African Areas," 26th January 1973, 1.

Ibid. , 3.

38 Nyambara, "A History of Land Acquisition in Gokwe," 246.

39 NAZ (RC), DC Gatooma - Ministry of Internal Affairs, Box 158098, Location C19.10.7R, DC's File: Gowe Irrigation Scheme 1965-1971: Plans etc., L. G. Leach to the PC Mashonaland South, 3rd April, 1968. 
(DC) by the co-operative for a communal loan. ${ }^{40}$ Provided that the previous year's communal loan was completely liquidated, approval was granted and the co-operative became liable for repayment. As the individual delivered his crop, the stop order was paid off first in the normal way, and as soon as repayment was completed, the individual received full payment for his produce, less the usual transport and handling charges. The co-operative, however, remained responsible for the repayment of the communal debt to the ALF.

As far as agricultural inputs were concerned, orders for physical input items were consolidated and a single order placed through the Union. Delivery was made to a single collection depot, which was the secretary's "hut," an African Development Fund store, a trading store or simply a shelter under a tree. The secretary and his committee handled distribution and the individual farmers collected and transported their own requirements. Delivery to the central depot (collection point) was by Union transport or contract transport arranged by the Union.

During the marketing season, seed cotton was delivered to the same depot by individuals, with individual identification on each bale. On delivery, a produce receipt recording the weight of cotton was issued, but no grade (value) was attached and no payment was made at that stage. Once a truckload had accumulated, transport was obtained from the Union and the cotton was delivered as a single consignment to the ginnery.

Individual bales were recorded on the Cotton Marketing Board paysheet under the "Yield Reference" heading, to enable the payment to be broken down to individuals by the Union. A notification and cash analysis was provided to the bank for payment on its next visit to the area, and the secretary and committee drew the cash and made

40 NAZ (RC), ARDA, Box 272099, Location R19.3.12.1F, File: ADA/MAR/2 Marketing - General, "Confidential Correspondence: Agricultural Development Authority - Co-operative Societies in African Areas," 26th January 1973, 3. 
payment to individual growers. ${ }^{41}$ Standard Bank Gatooma operated a mobile bank unit that serviced Gowe-Sanyati. This procedure entailed some delays in the processing of payments to the farmers. The delay from delivery to payout was approximately two weeks in normal circumstances. In other circumstances it was quite extended (i.e. up to three months).

From the grower's point of view, the co-operative's function of credit disbursement was not perceived in the same way. Some farmers saw the co-operative as fulfilling its function satisfactorily but others felt swindled by it. From the administration side, the communal responsibility for the loan ensured that at least some degree of individual creditworthiness was established before the committee approved the loan. Whilst problems occurred, the system nonetheless resulted in a debt recovery rate in excess of 95\%, a considerably higher figure than where individual responsibility was the rule. ${ }^{42}$

A number of Co-operative officers only referred to by N. S. Gwacha as Shipley, Charumbira, Gorora and Bhango served on the Gowe Co-op and dominated its affairs. Among them was Gwacha himself, whose main functions as Secretary included, checking the records of produce, issuing pesticides and ensuring that plotholders got loans. He wrote and prepared co-operative loan forms before they were signed by the chairman. ${ }^{43}$ Gwacha was virtually the accounting officer of the Co-op who used his position to influence loan disbursement to the plotholders.

41 Norman Savata Gwacha, Communal farmer and former Secretary, Gowe Cooperative Society, Personal Interview, Kusi Village, Sanyati, 15th May 2005. See also NAZ (RC), ARDA, Box 272099, Location R19.3.12.1F, File: ADA/ MAR/2 Marketing - General, "Confidential Correspondence: Agricultural Development Authority - Co-operative Societies in African Areas," 26th January 1973, 5 .

42 Gowe like other co-operatives also needed input assistance or credit. The Gowe Co-operative Society, whose first Chairman was Isaac Mutengo, sourced agricultural loans from the ALF through the Union on behalf of the irrigation plotholders. The Co-op operated under the Sebungwe Co-operative Union, which had its headquarters in Kwekwe and a sub-branch in Kadoma. At the head of the Co-op were many renowned Master Farmers. See Job Gwacha, Former plotholder, Personal Interview, COTTCO Depot, Sanyati, 9th January 1997.

43 N. S. Gwacha, Personal Interview, 8th January 1997.

TD, 3(2), December 2007, pp. 319-350. 
Every plotholder provided he was not a bad debtor was entitled to a loan because the majority of them did not have ample capacity to self-finance their own operations. Besides, cotton, which was the area's major crop, was labour and capital intensive. Without these loans, the idea of having this scheme in the first place would have been meaningless. However, although he does not openly admit it Gwacha used his vast influence in the Co-op to help his relatives, for example his own brother, Job, and others obtain loans. At a local level he is the one who made the final recommendation on who should get a loan and who should not. Invariably those who had kinship links with him did not only get favourable recommendations but practically were assured of receiving the loans which they used to purchase inputs and access technical advice. A great deal of them who were privileged to have kinship ties with Gwacha took full advantage of this to accumulate more wealth than their counterparts. They owned large heads of cattle and exhibited wealth in a number of other ways. ${ }^{44}$

Clearly, the embezzlement of funds by Co-op officials was quite rampant. The misappropriation of co-operative funds by secretaries for personal gain was a depressing and continuous problem. Because they were not full-time employees and coming as they did from the community and controlling more cash than was commonly seen in the area, the social pressure on the secretaries to misappropriate resources on behalf of relations was extremely difficult to resist. Although wary to talk about his brother, Norman's membership of the Gowe Co-op, in an interview Job confessed that from the 1960s to the 1970 s the major crop that gave farmers including his brother a lot of profit and untold riches was cotton. He pointed out that he grew the Alba seed variety which gave farmers more yield than the other cotton varieties and that it gave more profit when compared to crops such as

44 For example, when the Co-op was still functioning, Job Gwacha had a 60 strong head of cattle which, at the time of the interview, stood at 42 (a big number by many rural standards) because he sold some to pay school fees for his children and others had fallen prey to marauding cattle rustlers. He built a beautiful home for himself, owned many farming implements and his children attended some of the best boarding institutions in the area such as the Sanyati Baptist School. See Job Gwacha (COTTCO Records Clerk, former plotholder and Kusi Village communal farmer), Personal Interview, COTTCO, Sanyati Growth Point, 17th May 2005. 
wheat and maize. ${ }^{45}$ Illustrating his point further, he said:

The price of cotton (i.e. 8 cents per kilogram) was very lucrative. The price of maize was very low. A full $90 \mathrm{~kg}$ bag of maize sold for only $£ 1.6 \mathrm{~s}$. At that time, wheat prices were also low and the wheat variety they grew (i.e. the tall Tokwe variety) did not give good yields. ${ }^{46}$

The Gwacha example can be used to show that Norman's position in the Co-op gave him and his kinsmen access to credit and ultimately riches. As the loans were performance-related, every plotholder strove to do well but those with better access accumulated more than those with poor access to credit.

In the $1967 / 68$ season, N. S. Gwacha produced 50 bags of maize and 8 bales of cotton. Of his 1,4 hectares, 0,7 ha were planted to maize and the other half to cotton. His grade "A" maize and cotton were sold at the Grain Marketing Board (GMB) and Cotton Marketing Board (CMB) in Kadoma at £1.2s.6p per bag and 8p per pound respectively. ${ }^{47}$ Locally, maize produced in 1967 was sold at $\$ 3,00$ a bag and the Gowe Co-operative Society provided a useful service to its members

45 Job Gwacha, COTTCO Records Clerk, former plotholder and Kusi Village communal farmer, Personal Interview, COTTCO, Sanyati Growth Point, 17 th May 2005.

46 J. Gwacha, Personal Interview, 17th May 2005.

47 N. S. Gwacha, Personal Interview, 8th January 1997. Historically, the GMB began operations in 1931 as the Maize Control Board (MCB). In 1951, the MCB was renamed the Grain Marketing Board (GMB) and its mandate extended to several other products. Jones calls it Africa's first statutory marketing board. See William O. Jones, "Food-Crop Marketing Boards in Tropical Africa," Journal of Modern African Studies, 25(3), (1987), 375-402; William A. Masters, Government and Agriculture in Zimbabwe, (London: Praeger Publishers, 1994), 80-81 and C. F. Keyter, Maize Control in Southern Rhodesia, 1931-1941: The African Contribution to White Survival, the Central African Historical Association, Local Series, 34, (1978). 
by marketing their produce. ${ }^{48}$ The Sebungwe Union Transport, Carriers Transport, Swift, A. W. Transporters, the Fireson Transport Company (owned by a Somali transport operator based in Kadoma), and other private transport owners were often hired to ferry the farmers' produce to its respective markets in Kadoma. The local CMB and the GMB depots at Sanyati had not yet been established. These were set up in 1976 and 1989 respectively. ${ }^{49}$

Since 1967, in order to market produce, a plotholder at Gowe needed to be a registered member of the Co-op (with a Co-op number), and a holder of a Master Farmer certificate. ${ }^{50}$ This was part of the requirements for inclusion, but the stringency with which this criterion was applied eventually led to the exclusion of so many irrigation plotholders who could not transform themselves into master farmers over night to ensure inclusion. In fact, nearly all of the government credit and agricultural advice available for African irrigation plotholders was directed, through the co-operative society, at this relatively small group of Master Farmers. It was believed that because they possessed vast farming skill their repayment capacity would also be high. Nevertheless, whether one had master farmer certification or not it was imperative to be registered and have a number allocated by the society to facilitate marketing.

48 NAZ (RC), Ministry of Internal Affairs, Box 86732, Location 8.17.5F, File: Annual Report 1967, "Acc.8/160 Report of the Secretary for Internal Affairs for the year 1967," 11 .

49 N.B. It had been argued in the TILCOR preliminary project report that the establishment of the scheme should be followed by the establishment of a local cotton ginnery for the processing of the cotton crop, but this did not materialise until much later. Gatooma is where cotton was mainly marketed before the establishment of the Cotton Marketing Board (CMB) depot at Sanyati Growth Point in 1976. CMB is now the Cotton Company of Zimbabwe Limited (COTTCO). 
The Co-op number indicated the produce items a farmer was dispatching to the market. In turn, the Co-op had a Growers card or number on which it sold plotholders' produce. J. Gwacha vividly remembers that in the $1967 / 68$ season his Co-op number which it was compulsory to stick onto each bale of cotton as a label before dispatching a consignment of cotton to the market, was 229, and the Co-op Growers card number was 027206A. ${ }^{51}$ It should be pointed out here that, before the CMB was formed as an arm of the Agricultural Marketing Authority (AMA), the Gowe plotholders marketed their cotton through the Cotton Company Committee (CCC), which was based in Kadoma. ${ }^{52}$

The CMB was only created in terms of the Cotton Marketing and Control Act Chapter 106 in 1969, ${ }^{53}$ which made the Co-op's marketing arrangements rather cumbersome since inception.

After the plotholders had sent their produce to the market, the Gowe Co-operative Society would receive cheques from the GMB and CMB, which in turn would be cashed by the Co-op officers at the Kadoma Standard Bank Branch. ${ }^{54}$

Eventually, the farmers would be paid in cash by the Co-op officers or the Standard Bank but on production of a "producer's statement." 55 This ensured that the money would not be paid out to unscrupulous claimants, but subordination of the Co-op to Sebungwe sometimes disadvantaged the growers. The latter were invariably forced to pay certain dues to keep the Union afloat.

51 Ibid.

52 J. Gwacha, Personal Interview, 9th January 1997.

53 Cotton Marketing and Control Act, Chapter 106, 1969, 39. The CMB (now COTTCO) operates in close co-operation with the GMB as the sole buyer of raw cotton and processor of lint and seed. See Masters, Government and Agriculture in Zimbabwe, 81 and Cotton Marketing Board (CMB), (various years), Annual Reports, Harare: CMB.

54 N. S. Gwacha, Personal interview, 8th January 1997.

55 Ibid.

TD, 3(2), December 2007, pp. 319-350. 
As the main Co-op was required to guarantee plotholder borrowings it, as a result, incurred crippling debts because some of them failed to meet their financial obligations to Sebungwe. In fact, the previously close relationship between the co-operatives and the agricultural credit institutions became strained as the latter continually demanded guarantees before granting loans. This is linked to the many problems associated with financing co-operatives most of which were increasingly in debt. In this connection the former DC Gatooma, R. L. Westcott, lamented the fact that "Sebungwe covered a larger area than Gowe and consequently introduced costs which were not applicable and delays of up to three months in payments to the plotholders were quite commonplace." 56

From an economic point of view, the Gowe Co-op also needed to survive by charging a "small" service fee. For instance, the Co-op bought seed, pesticides, fertiliser and other essential inputs from the Zimbabwe Fertiliser Company (ZFC), Windmill and Agricura. ${ }^{57}$ It then sold these to the plotholders at the Co-op's own mark up price. The Co-op's price took into account its handling charge or service fee. The money that accrued to the Co-op as a result of services rendered to the plotholders was used by the former to repay its own debts/ loans to the ZFC, Windmill and Agricura. ${ }^{58}$

Sometimes the DC marketed plotholders' produce on their behalf. T. Nyamutova, one of the well-to-do farmers at Gowe remembers that all plotholders grew and sold their crops on one growers card on the advice of the DC. "We produced on one card and got our money from the DC after deducting the cost of inputs such as seed and fertiliser."

56 R. L. Westcott, Former DC Gatooma, Personal Interview, Ramsgate, South Africa, 12th July 2005.

57 J. Gwacha, Personal interview, 9th January 1997.

58 Ibid. 
${ }^{59}$ However, the DC was an employee of the Ministry of Internal Affairs whose Co-operatives Branch administered the Co-operative Societies Act. Whilst there were problems associated with marketing produce through the Gowe Co-op, the co-operatives clearly represented a very convenient way for the plotholders to obtain their input items. The majority of co-operatives notwithstanding the hitches pointed out by Gwacha processed their orders efficiently and the goods were supplied practically at the user's doorstep. This compares favourably with the alternative of ordering personally from outlets in the main centres, then depending on unreliable local contractors for the transport of these goods.

The control and organisation provided by the co-operatives was great. From the grower's point of view, the convenience of marketing through the co-operative brought considerable relief especially to the resource-poor plotholders who could not afford to buy input requirements for cash. From the Cotton Marketing Board point of view, the consolidation of Gokwe District's (which included Sanyati) 1935 individual growers into only 19 accounts reduced drastically the volume of administrative work involved. ${ }^{60}$ Nevertheless, not all producers save for the resource-rich and consistent performers qualified for these loans. The other category found it difficult to access credit and this impeded accumulation. Thus, the Gowe Co-op's activities became more characterised by tendencies towards exclusion than inclusion.

This, therefore, confirms the general belief that for many farmers, cooperatives represented both "carrot and stick." ${ }^{61}$ For instance, while members were provided access to credit through the ALF, it also meant that they had to market through official marketing boards, for example, the GMB and CMB. This had many drawbacks. One was that the

59 Nyamutova, Personal Interview.

60 NAZ (RC), ARDA, Box 272099, Location R19.3.12.1F, File: ADA/MAR/2 Marketing - General, "Confidential Correspondence: Agricultural Development Authority - Co-operative Societies in African Areas,” 26th January 1973, 2 and 6 .

61 Nyambara, "A History of Land Acquisition in Gokwe," 249.

TD, 3(2), December 2007, pp. 319-350. 
marketing boards provided stop-order arrangements to ensure loan repayments or recovery. ${ }^{62}$ For poorer farmers this increased the sense of risk and insecurity associated with their vulnerability to drought and poor harvests. ${ }^{63}$ The other was that it was not economically viable for farmers to wait for up to three months for cash payments after delivering their produce to the market. This was the period the farmer was often in dire need of cash to prepare for either the winter or summer crop.

The farmers who failed to get their payment on time planted late and the late planted crops produced lower yields. Low yields meant poor repayment capacity and a combination of the two was often used by the Co-op to exclude a farmer from accessing inputs for the next cropping season.

\section{Inclusion and exclusion gowe irrigation scheme}

\section{Social exclusion}

As already noted, the Gowe Co-operative Society was construed with the object of uplifting the lives of the smallholder irrigators in Sanyati. The Co-op was to facilitate, inter alia, the procurement of inputs, credit or loans and arrange for the marketing of farmers' produce. Such services, often brought at the smallholder irrigator's "doorstep," meant

62 NAZ (RC), Ministry of Internal Affairs, Box 153673, Location C36.18.2F, File: AGR/16/A/15 Vol. 1, Gowe Irrigation Scheme (August 1965 - December 1969), R. L. Westcott to the PC Mashonaland South, 10th December 1969.

63 William Munro, "State, Peasants and Community Development in Zimbabwe, 1948-1988: Control, Consent and the Limits of State Power." PhD dissertation, Yale University, 1991, 229 and Whitsun Foundation, Agriculture in Rhodesia, (Salisbury: Whitsun Foundation, March 1977), 11. 
that the outgrower ${ }^{64}$ would not travel long distances to secure these vital services from far away places such as Hartley (now Chegutu), Gatooma, Que Que, Gwelo (Gweru) and sometimes Salisbury (Harare). The assumption was that this localised agency (the Co-op) would allow the irrigators to concentrate on production and realise high yields. Nevertheless, the criteria for eligibility to membership of such associations was iniquitous. Members were required to be in possession of master farmer certification or a proven farming record.

Their loyalty to the scheme and the DC who initiated it had to be impeccably high. The strictness of membership eligibility conditions and the excessive demands for loyalty were constraining in their effect as this determined the benefits the tenants derived from cultivating their 3 to 4 -hectare standardised plots allocated per holder. ${ }^{65}$ Clearly, the benefits the farmers enjoyed from being members of this institution were mixed. Some small-scale irrigators particularly those who had bureaucratic connections within the Coop movement became noticeably rich.

They became some of society's most eminent groups. Others who had not forged this kind of link with either the state or the Co-op officials invariably turned out to be poor. One of the Gowe Co-op's major objectives was to assist the farmers achieve self-provisioning status which was central to the eradication of hunger and poverty in this frontier or backwater region of the country.

In practice, though, poverty alleviation was not accorded much attention in spite of the fact that it should have been a paramount consideration if the Co-op was to be continually perceived in good light by all the irrigation farmers who looked up to it for economic prosperity. Furthermore, the Co-op epitomised a local and decentralised branch of state administration and exclusion was

64 At ARDA Estates the small-scale farmers who have been allocated some pieces of land adjacent to the Main Irrigation Schemes are known as tenants, outgrowers, plotholders, smallholders, settlers or simply peasants. However, between 1967 and 1973 it is erroneous to call them outgrowers because the core Estate had not yet been established. It was set up in 1974. Thus, the Gowe Smallholder Scheme pre-existed the Main ARDA Scheme.

65 Smallholder irrigators at Gowe were allocated plots of approximately the same size. These ranged between 3 and 4 hectares per holder. 
fundamentally tied to the very nature of the colonial government, which was not as inclusive in its broader agricultural policies.

In the words of Rodgers and C. Safiliou-Rothschild, poverty is almost everywhere a manifestation of social exclusion. ${ }^{66}$ Whereas poverty describes a state of multidimensional deprivation, ${ }^{67}$ the concept of social exclusion points to the process by which society systematically and structurally excludes particular groups, like poor people, from assets, goods and services, rewards of production, rights, and valued economic and social resources.

The Co-op, therefore, became synonymous with an institution that would include or exclude. The irrigators who were included (i.e. those who had easy access to the above-named assets) constituted a class of rural notables, but those who were excluded were deprived of these assets and hence denied the opportunity to ascend to a position of prominence.

An examination of the operations of the Co-op during its short-lived tenure (1967-1969) reveals that it's distribution of input resources and credit (i.e. economic and social opportunities) or its monopolisation by certain groups or "the mainstream," was deleterious to the interests of the other groups notably the poor groups. Influential groups within the Co-op restricted access to these resources by others, or enforced disadvantageous terms of inclusion. For example, no plotholder from Gowe could access irrigation inputs and other requisite farming resources unless he/she met certain stringent criteria. His/her creditworthiness needed to be attested to by the Co-op authorities.

Failure to repay loans advanced to an irrigator or a poor repayment record determined whether a farmer would be included in the list for the following season's supply of farming requirements or not. Continued indebtedness, thus, allowed the exclusion of certain groups in the Gowe Smallholder/Tenant Irrigation Scheme to persist.

66 Rodgers, 1994, and C. Safiliou-Rothschild, 1998 cited in Barbara van Koppen, More Jobs Per Drop: Targeting Irrigation to Poor Women and Men, (Amsterdam, Netherlands: Royal Tropical Institute KIT, 1998), 20.

67 Mellor and Desai, 1985; World Bank, 1990; Chambers et al, 1989; and Jazairy et al, 1992 cited in van Koppen, More Jobs Per Drop, 20. 
Quite significantly, the Co-op was, on the one hand, an excluder primarily because it operated in the interests of the dominant groups. It promoted a lending policy which failed to integrate particular groups or integrated them against their will or disbursed inputs unequally on the pretext that those who were not given credit were owing or were in arrears. On the other, it was an all-embracing body, which acted as the main agent of the redistribution of seed, fertiliser and chemicals (pesticides and insecticides).

This function was enhanced by its practice of reconciling every irrigator's total budgetary requirements not least its role as guarantor of loans extended to the farmers by other lenders such as the DC (the state) and the Agrochemical Industry (Windmill, Agricura and Shell Chemical). In this sense, inclusion was not voluntary but compulsory, as non-members of the Co-op were not entitled to Co-op benefits. It (inclusion) was, thus, forced because the terms of inclusion were imposed from above and were frequently unacceptable to the plotholders. In fact, there was no mass participation or no popular involvement of the tenants in the decision that led either to the formation of the Gowe Co-op or who would be a member and who would not. Pressure for a more people-oriented Co-op, apart from the rampant managerial ineptitude, threatened the organisation with collapse.

The ultimate collapse of the Co-op in 1969 was accompanied by a sudden drying up of Co-operative Society loans. This threatened to exclude so many tenants from carrying out irrigation at Gowe had it not been for the not so timely but frequent central intervention. Above all the involvement, since the inception of the scheme, of other input/ credit providers such as the ADF and the ALF helped make this experiment work.

Traditionally, government intervention often promoted exclusion more than inclusion. In many such situations it is normal that the excluded develop coping strategies to advance their own inclusion and their participation on their own terms. However, this was said not to be the case at Gowe-Sanyati where the excluded instead of fighting for their inclusion actually assumed a bizarre passiveness and despair. Such a mysteriously passive and despondent approach is believed to have accentuated their exclusion not only from social, but also from economic and to some extent political facets of life, thus, confirming the fact that exclusion in one domain can reinforce exclusion in other domains. This is clearly a misrepresentation of reality as evidence to the contrary is galore.

The plotholders did not just resign themselves to fate in the face of disadvantageous terms of inclusion. They fought the negative effects of the Co-op, which partly explains its demise in 1969. These 
smallholders were not inevitably powerless and perpetually vulnerable to exploitation as seen in Sanyati where they have acted effectively and have developed the political and economic voice necessary to influence the demise of the Co-op. ${ }^{68}$ Therefore, the received wisdom that smallholders are incapable of counteracting the harmful agricultural policies of governments and related institutions should be discarded. Despite peasants exhibiting such a strong voice, in the colonial period, it was however very difficult to force the government to recognise the importance of women in agriculture and land related issues. The disadvantages and exclusion faced by female plotholders or plotholder aspirants are least discussed but they were quite pronounced at Gowe. In fact, exclusion was also gendered.

\section{Gender, poverty and social exclusion}

Core issues in rural poverty are exclusion from land and productive assets, from inputs and goods markets, or inclusion on unfavourable terms, and the absence of remunerative off-farm employment. ${ }^{69}$ In all these respects, women often face a greater degree of exclusion. The need to include them in mainstream socio-economic development and on better terms was imperative. Nevertheless, with the exception of one or two odd cases at Gowe, the DC did not consider them for allocation of irrigation plots. ${ }^{70}$ It was also not easy for them to access farm inputs, markets and other essentials. The Gowe Cooperative Society only advanced input loans to incumbents of plots who were mainly male household heads. Colonial policy in Zimbabwe regarded women as minors who were not entitled to possession of land let alone credit. ${ }^{71}$ Such laws also implied that women's control

68 For more detailed discussion of smallholder or peasant resistance to exploitationary tendencies in Zimbabwe and Tanzania see Stephen F. Burgess, Smallholders and Political Voice in Zimbabwe, University Press of America, New York, 1997, 1 and Goran Hyden, Beyond Ujamaa in Tanzania: Underdevelopment and an Uncaptured Peasantry, (London: Heinemann, 1980).

69 Van Koppen, More Jobs Per Drop,21.

70 Nyamutova, Personal Interview.

71 E. Schmidt, Peasants, Traders and Wives: Shona Women in the History of Zimbabwe 1870-1939, (Harare: Baobab Books, 1992). 
over co-operative society affairs in Sanyati was proscribed by their very minimal if not non-recognition in land distribution processes and other governmental programmes both in the rural and urban areas. Gowe records are also silent on why there was no female cooperative officer in the 1960s. The more women were sidelined the less benefits of access to inputs and other co-operative services accrued to them.

Equal access to inputs and other services provided by co-operative societies should lead to improved food or agricultural production. However, at Gowe no equal access was guaranteed given the corrupt tendencies inherent in the Co-op. The Co-op tended to be a male dominated affair. Even within the male domain some plotholders got more inputs and at more appropriate times in the growing season than others. The Gwacha family and those with whom they had close kinship ties found themselves in a more favoured position. Marketing crops through the Co-op also meant that the terms of inclusion in the agricultural produce markets were also disadvantageous for many irrigation tenants. They were intrinsically "tied" to one buyer i.e. the Co-op even if there were alternative markets elsewhere.

For example, black-marketing of produce was more lucrative than selling produce through the official marketing channels. Official and traditional marketing agencies like the GMB and the CMB offered very low prices to the farmers. Distance to such markets situated in far away centres like Gatooma and Que Que was another big impediment. In addition, the road infrastructure to the market was often inadequate. Information on prices was also rarely available to the farmers before the planting season. They were merely told when to plough, what to grow and at what time (i.e. synchronisation of activities), but did not take part in price determination. This intensified their problems as the Co-op hardly fought for price improvement because its interests lay with the state, which was pushing for low prices.

Although the core business of the Gowe Co-operative Society was to facilitate development of smallholder irrigation through the undivided and timeous provision of the necessary inputs and related services to the plotholders, in practice, the Co-op excluded some Sanyati peasants in agricultural development. This was done through its activities, which were not always transparent and which vested benefits derived from the Co-op in some of the farmers and not in others.

Given the multifarious problems faced by the Co-op from the date of its inception such as lack of financial viability, violation of the basic principles of co-operation, lack of satisfaction of member objectives, lack of growth in membership and business, and insensitivity to 
member involvement in the co-operative's affairs, its survival could not be guaranteed. Members' economic well-being was largely ignored. All this, coupled with maladministration and corruption within the Co-op made its collapse inevitable in 1969 when lines of credit were frozen. Failure to service debt led to a further straining of relations between the Gowe Co-operative Society and the agricultural credit institutions. With all sources of funding having dried up the Co-op could hardly fill its traditional role of input supplier to the plotholders. This situation, therefore, forced the society that had served Gowe for about three years to fold up. Although the idea of cooperative enterprise in rural agriculture was resuscitated in the early 1970s, it had suffered a major setback towards the end of the previous decade. Co-operative ventures in the post-1969 period are, however, beyond the scope of this study.

\section{Conclusion}

It can therefore be concluded that instead of playing an all-inclusive role the Gowe Co-operative Society in Sanyati was a typical example of an institution that satisfied the needs of some people and not the needs of others. Therefore, the Co-op, which was supposed to act in the interests of the small-scale irrigation farmers, was eventually embroiled in a process that became highly exclusivist and one that also marginalised the very people it was designed to benefit. That the Co-operative, between 1967 and 1969, was one of the major providers of inputs and credit to the irrigation plotholders became the means to coerce compliance to some of its unpalatable dictates. The collapse of the Co-op was obviously a vote of no confidence for an institution that had clearly stood for exclusion and not wholesale inclusion of the plotholders in its developmental strategy. It was also necessitated by the withdrawal of support by the irrigation tenants themselves because the conditions that guaranteed inclusion of this largely poor group of plotholders remained unmet.

The Gowe Co-operative's corrupt tendencies and inept management compromised the principles of African economic empowerment and national development. It is also axiomatic that altruistic motives towards the irrigation plotholders were not high on the agenda both of the officials directing co-operative development in Sanyati and the state which they represented. The poor management of the credit programme administered through the Gowe Co-op undoubtedly contributed to a serious weakening of agricultural productivity in the area. The availability of credit which was neither properly 
accounted for nor equitably disbursed by the Co-op officials undoubtedly played a part in the decay and subsequent disintegration of the co-operative movement in Sanyati irrigation.

Ideally, a co-operative society should be central to its members' livelihoods. If it ceases to address the critical issues in the well being of its members then it faces opposition and neglect which are bound to lead to its eventual downfall. Instead of being central to the needs of its members, the Gowe Co-op became peripheral to them. This is contrary to the advocacy by some studies that indicate that "a nation's co-operative sector is a thriving, competitive system, harmoniously catering to the needs of farmer members and, indeed, to the entire agricultural sector in positive and profitable ways, under democratic control." ${ }^{72}$ In reality, however, this was not always the case. The Gowe co-operative organisation, in many specific ways, often deviated from this ideal and its ultimate folding up did not come as a big surprise as its collapse was already a foregone conclusion given its inefficient manner of operation throughout its existence.

72 Foxall, Co-operative Marketing in European Agriculture, ix. 


\section{REFERENCES}

Balawyder Aloysius (ed.), Cooperative Movements in Eastern Europe, London: MacMillan Press Ltd., 1980.

Bates Robert H., Markets and States in Tropical Africa: The Political Basis of Agricultural Policies, Berkeley: University of California Press, 1981.

Bonner Arnold, British Co-operation, Manchester: Cooperative Union, 1961.

Burgess Stephen F., Smallholders and Political Voice in Zimbabwe, New York: University Press of America, 1997.

Chicheko E. N. S., "A History of Cotton Growing in Sanyati (19681990)," BA Honours dissertation, Harare: Economic History Department, University of Zimbabwe, 1992.

Cotton Marketing Board (CMB), (various years), Annual Reports, Harare: CMB.

Foxall Gordon R., Co-operative Marketing in European Agriculture, Aldershot, Hampshire, England: Gower Publishing Company Limited, 1982.

Grossman Gregory, "The Second Economy of the USSR," Problems of Communism, 26(5), September-October 1977.

Gwacha Job, COTTCO Records Clerk, former plotholder and Kusi Village communal farmer, Personal Interview, COTTCO Depot, Sanyati Growth Point, 9 $9^{\text {th }}$ January 1997 and $17^{\text {th }}$ May 2005.

Gwacha Norman Savata, Communal farmer and former Secretary of the Gowe Irrigation Co-operative Society, Personal Interview, Kusi Village, Sanyati, $8^{\text {th }}-9^{\text {th }}$ January 1997 and $15^{\text {th }}$ May 2005.

Gwerengwe J., "Sanyati Estate Corporate Plan," ADA, 1995.

Hanel A., State-Sponsored Co-operatives and Self-Reliance, Marburg: Institute for Co-operation in Developing Countries, 1989.

Harper Malcolm and Roy A. K., Co-operative Success: What Makes Group Enterprise Succeed, London: Intermediate Technology Development Group/ITDG Publishing, 2000.

Hunter G., Modernising Peasant Societies, Oxford: Oxford University Press, 1969.

Hyden Goran, Beyond Ujamaa in Tanzania: Underdevelopment and an Uncaptured Peasantry, London: Heinemann, 1980.

ICA, "Agenda and Reports," Review of International Co-operatives, 8(3), 
Manchester: ICA Congress, 1995.

ILO, Co-operative Management and Administration, Geneva: International Labour Office, 1971.

Jones William O., "Food-Crop Marketing Boards in Tropical Africa," Journal of Modern African Studies, 25(3), 1987.

Keyter C. F., Maize Control in Southern Rhodesia, 1931-1941: The African Contribution to White Survival, the Central African Historical Association, Local Series, 34, 1978.

Masenga A., Gowe Pump Attendant, Personal Interview, Gowe, Sanyati, 8 ${ }^{\text {th }}$ January 1997.

Masters William A., Government and Agriculture in Zimbabwe, London: Praeger Publishers, 1994.

Munro William, "State, Peasants and Community Development in Zimbabwe, 1948-1988: Control, Consent and the Limits of State Power." PhD dissertation, Yale University, 1991.

Murimi, December 1966; Press Statement, "Gokwe farmers have record cotton crop," Ministry of Information, 7 December 1966.

National Archives of Zimbabwe (Records Centre) hereafter referred to as NAZ (RC), ARDA, Box 272099, Location R19.3.12.1F, File: ADA/MAR/2 Marketing - General, "Confidential Correspondence: Agricultural Development Authority - Cooperative Societies in African Areas," 26 th January 1973.

NAZ (RC), DC Gatooma - Ministry of Internal Affairs, Box 158098, Location C19.10.7R, DC's File: Gowe Irrigation Scheme 19651971: Plans etc., L. G. Leach to the PC Mashonaland South, $3^{\text {rd }}$ April, 1968.

NAZ (RC), DC Gatooma, Ministry of Internal Affairs, Box 158098, Location C19.10.7R, DC's File: Gowe Irrigation Scheme: Financial Plans, Water Reports etc, 1967-1971, "Sanyati Irrigation Plots."

NAZ (RC), DC Gatooma - Ministry of Internal Affairs, Box 158098, Location C19.10.7R, File: "Gowe Irrigation Scheme: Sanyati TTL (EX CONEX)," Minutes of a meeting held at Gowe Irrigation Scheme on $5^{\text {th }}$ May, 1969, 1.

NAZ (RC), Ministry of Internal Affairs, Box 86732, Location 8.17.5F, File: Annual Report 1967, "Acc.8/160 Report of the Secretary for Internal Affairs for the year 1967."

NAZ (RC), Ministry of Internal Affairs, Box 153673, Location C36.18.2F, File: AGR/16/A/15 Vol. 1, Gowe Irrigation Scheme (August 1965 - December 1969), R. L. Westcott to the PC Mashonaland 
South, 10 ${ }^{\text {th }}$ December 1969.

NDDB, A Note on Co-operative Development, Anand, India: National Dairy Development Board, 1991.

Nyambara Pius S., "A History of Land Acquisition in Gokwe, North Western Zimbabwe, 1945-1997," PhD Dissertation, North Western University, Evanston, Illinois, June 1999.

Nyamutova T. Vice Chairman, Gowe Irrigation Committee, Personal Interview, Gowe, Sanyati, 14 ${ }^{\text {th }}$ May 2005.

Nyandoro Mark, "The Gowe Plotholders Scheme: Growth and Development of an African Irrigation Enterprise in the Sanyati Communal Lands (1960s-1990s), MA thesis, Harare: Department of Economic History, University of Zimbabwe, June 1997.

Schmidt E., Peasants, Traders and Wives: Shona Women in the History of Zimbabwe 1870-1939, Harare: Baobab Books, 1992.

Shah Tushaar, Catalysing Co-operation, New Delhi: Sage, 1996.

Shah T. and Mishra D., "Analysing Under-Performance in Indian Cooperatives," Small Enterprise Development, 3(1), 1993.

Srivastava H. O. and Chaturvedi M. K., Rural Middlemen, New Delhi: Ashish, 1986.

Van Koppen Barbara, More Jobs Per Drop: Targeting Irrigation to Poor Women and Men, Amsterdam, Netherlands: Royal Tropical Institute KIT, 1998.

Weinrich A. K. H., African Farmers in Rhodesia, London: Oxford University Press, 1975.

Westcott R. L., Former DC Gatooma, Personal Interview, Ramsgate, South Africa, 12 $2^{\text {th }}$ July 2005.

Whitsun Foundation, Agriculture in Rhodesia, Salisbury: Whitsun Foundation, March 1977. 